\title{
The Effects of Alliance Strategies on the Cost Efficiency of Saudi Commercial Banks
}

\author{
Hassan K. Almahdi \\ Dean of Jazan College of Business Administration, Jazan University, Saudi Arabia
}

Received: September 19, 2018 Accepted: October 9, 2018 Published: January 10, 2019

doi:10.5296/ber.v9i1.14208

URL: https://doi.org/10.5296/ber.v9i1.14208

\begin{abstract}
The Objective of this study is to determine the influence of strategic alliances on the cost efficiency of Saudi banks. For this, we first develop a theoretical framework paving the way for an empirical study that refers to a sample of 09 Saudi banks adopted to verify this relationship. It is therefore, necessary to list the interests of strategic alliances in the banking sector and to question the role of public and foreign as wellas public and private alliance strategies in improving the cost efficiency of Saudi commercial banks.

A quantitative approach has been adopted to explore and understand the research problem. We begin by regressing the ordinary least squares efficiency on a series of explanatory variables. The conceptual research model is tested by two different regression equations that will be estimated simultaneously. The first regression, aims to test the impact of the public-foreign alliance on the efficiency of the banks in our sample. As for the second regression, it is carried out to test the impact of the public-private alliance on the latter.

The results of this study prove that the creation of an alliance agreement allows Saudi commercial banks to improve their efficiency and constitute for them an opportunity besides an interesting strategic option. Forthermore, public-private and public-foreign alliances are strategies that can improve the efficiency of public banks, increase their competitiveness and reduce their fragility.
\end{abstract}

Keywords: Strategic alliance, Cost efficiency, Public bank, Private bank, Foreign ban, DEA, SFA

\section{Introduction}

It is universally recognized that a bank operates in an unstable and a constantly changing environment. This certainly requires a synergy of activities and collaboration between banks in order to eradicate competitive positions. To ensure this, it is wise to use the application of the so-called strategic alliance (Margherita Russo 1 and Maurizio Cesarani (2017) . 
In light of these conditions, many controversies, studies and analysis by academicians and practitioners specializing in strategy like, Cummings and Holmberg, (2012), Schreiner et al., (2009) (Margherita Russo1 \& Maurizio Cesarani (2017) analyzed the interest of strategic alliances as well as the motivations of this operation and its effects on the performance of companies through the development of its advantages and disadvantages. The two streams of thoughts to be distinguished in the literature: the first that considers alliance strategies to ensure resistance, sustainability, and value creation (Shi et al., 2012) and corporate competitiveness ( Agarwal and Bayus, 2002, Garvin and Levesque, 2006, Franco et al., 2008, Eggers and Kaplan, 2009, Davies and Arogundade, 2014) through good management and better organization, monitoring and regular monitoring of the development path, the strategy carried out all through the exercise, sharing of experiences (Sorrentino and Garraffo 2012, Shi et al., 2012), knowledge (Lubello et al., 2015), and skills (Colombo et al. 2006, Faems et al., 2005;). In addition, the ease of access to information specific to each ally, the exploration of new markets, the creation of new products and services and new relationships with the various players, mastering new technologies (Colombo et al., 2006, Hoffmann, 2005). Indeed, from Barney's point of view, 1991; Wernerfelt, 1984 the founders of the resource-based theory (RBT) of companies have explained alliances as strategies that generate superior performance and profits and whose fruits will be distributed among the various stakeholders who have engaged in this collaboration (Kale and Singh, 2007, Lambe et al., 2002).

However, the second thought states that this operation generates costs and risks that threaten the sustainability of companies. Tonnel (2012) has argued that the strategic alliance is a source of conflict that will necessarily have adverse effects on the performance of companies. Kale \& Singh, (2009) states that about 50\% of strategic alliances are underperforming and ultimately fail.

Alliances between banks are one of the strategies of rapprochement that marked the global economic and financial sphere from the 80s. Admittedly, this era is often considered as a transition phase escorted by a storm of change and deregulation. This, therefore, explains the recourse of some banks to ally in order to face the threats of an environment which is often in perpetual evolution, to reach competitive positions (Cobeña et al., 2017) and to ensure their survival (Margherita Russo1 \& Maurizio Cesarani , 2017) by improving the various indicators of profitability and growth.

This strategy (Contractor and Lorange, 1988, Dussauge P., 1990, Koenig, 1990) is considered as an opportunity or a means of generating performance and creating a competitive advantage. It is, In addition a theme that has been among the concerns of theoretical and academic researchers. Various results have been established that have given rise to different conclusions and findings. Certainly, like every strategy, alliances can be financially beneficial through profit maximization Chia-Nanet al (2018), the minimization of risks, the possession of a good reputation via its brand image, improving skills, and increasing market share. As they may be evil strategies that end in the inability to maintain one's autonomy, to protect one's identity, to resist and even to be incapable of exercising control throughout this agreement. Thus, the success or failure of an alliance between two companies depends on several factors such as the convergence of objectives, the degree of understanding, the confidence and the weight of 
the allies. Elmuti dan Kathawala (2001); Zineldin and Bredenlow (2003) theoretically defined several problems faced by the alliance, namely: lack of coordination among management teams, differences in procedures and attitudes among partners, ambiguity of goals and objectives, lack of trust and opportunistic behavior, and risk performance due to external factors, market factors and internal factors, high risk related to different resources and uncertain investments, lack of experience. From what precedes the strategic alliance can be a source of risk, of disorder, of conflict and ends up being expensive.

Previous research has indicated that the failure rate of alliances is greater than or equal to $50 \%$ (Lorange and Ross 1992, Bleeke and Ernst 1993, Faulkner 1995, Bamford et al. 2004, Lunnan and Haugland 2008). , Kale and Singh, 2009, Madhok et al., 2015, Linwei et al., 2017).

Strategic alliances are considered as formal and voluntary agreements between allies while maintaining the independence of each party Mowla (2012). These may be in the form of co-operation or co-exploration or research and development. They are articulated on the basis of the principle of association and sharing of means, capacities, skills and resources to provide benefits (Shi et al., 2012, Kristal et al., 2010, Parmigiani and Rivera-Santos, 2011). It should also be noted that alliances are subject to norms and rules enacted by law. In addition, it is essential to carry out throughout this operation monitoring and control of the behavior of the various parties regularly. The rate of business-to-business alliances has increased dramatically as a result of increased competition and instability in the current environment (Vazquez et al., 2006).

This research aims to study the effects of strategic alliances on the performance of the banking sector, specifically that of Saudi commercial banks. Indeed, the interest generated by the banks in setting up strategic alliances is explained by the specificity and the delicacy of their activities in the context of perpetual evolution. Their concerns to achieve objectives that they are not able to accomplish alone to the satisfaction and the needs of their customers by offering innovative and attractive products and services, satisfaction, diversification and the capture of market share internationaly, encourage them to ally themselves with partners with significant weight in order to face the handicaps likely to be involved, improve the performance, and ensure the success of this agreement ((Uddin dan Akhter, 2011; Diestre \& Pajagopalan, 2012). The success and sustainability of the alliance is certainly dependent on the value of the different partners (Kale and Singh, 2009). convergence of their orientations and their ability to manage this alliance (Schreiner et al., 2009) are also factors that can lead to a successful alliance. Indeed, it is wise to analysis, monitor and follow with vigilance all phases of this strategy from its launch until its completion. With the establishment of comparative analyzes relating to the variations of the different performance indicators throughout this agreement and compared it to the previous period and compared to competitors operating in the same sector.

Over the last decades, the financial sphere has experienced a wave of reorganization through reconciliation and cooperation. The financial services sector is believed to be the most dynamic in the global M\&A market. In 2017, according to data from Thomson Reuters, 
global business mergers and acquisitions ( $\mathrm{M} \& \mathrm{~A}$ ) achieved a record \$ 3.6 trillion worth 2.993 billion euros, and a higher number of transactions compared at the beginning of the surveys in 1980. The latter increased by $50 \%$ in 2017 to reach 245.8 billion dollars (205 billion euros).

There is an abundant literature specific to the financial sector (Fiordelisi, 2009 and DeYoung et al., 2009) dealing with consolidation and integration in the banking sector since it is supposed to be the most important subject to these phenomena. While, there are other forms of reconciliation for financial firms, such as strategic alliances and joint ventures (Koh and Venkatraman, 1991, Merchant and Schendel, 2000, Meschi and Cheng, 2002, Gulati et al., 2009).

Banks abroad have often used these strategies mainly in the United States (Gleason et al., 2003, Marciukaityte et al., 2009) and Japanese financial firms (Chiou and White, 2005) and in Europe. .

Based on the above facts, the use of alliance strategies reflects the willingness of banks to achieve abnormal returns as well as strengthen their competitive positions and resist the market competition.

Banks operate in an environment dominated by intense competition, modernization of technologies followed by an unstable macroeconomic environment and many shocks that could affect their performance. However, the banking sector has become heterogeneous and turbulent with the proliferation of diversified synergy operations between domestic and foreign banks or between public and private banks. This fosters the performance of banks and improves the financial services and products offered to a demanding clientele and ensures the survival and resilience of banks to different fluctuations.

\section{Review of the Literature and Theoretical Background}

Douma (1997) defines the alliance as a contract that temporarily links two or more companies so that they can achieve their goals in fluctuating and dangerous environmental conditions and with insufficient resources and capacity. Certainly, strategic alliances are essential to penetrate new markets, develop product lines, acquire new skills and share knowledge (Shi et al., 2012; Mu \& Di Benedetto, 2011; finance investment in R \& D , maximize rents (Vazquez et al., 2006), leverage new technologies, reduce information asymmetries, achieve economies of scale, minimize costs and share risks, manage interdependence (Mitsuhashi, 2002 ) and resist in an unstable and competitive environment (Buggleman (2000).

Certainly, the strategic alliance ensures the implementation of new concepts, means and resources likely to offer new products and services of better quality. Udin and Akhter (2011), state that this strategy for strategic purposes is essentially the acquisition of a competitive advantage.

An alliance is one of the modalities of strategic orientation that aims at Diversification, Internationalization, Innovation. It is a cooperation between two or more companies ( Ferreira et al, 2014) through the pooling of skills, resources and means to maximize rents and 
minimize risks. This strategy makes it possible to penetrate new markets, create products, reduce costs and make investments profitable, acquire new skills, increase the size and diversify partners.

An alliance is an agreement that connects two or more organizations that wish to unite in order to improve their performance, expand their market share, diversify, reflect a new and good image in the market, improve their competence and most importantly compete with their rivals (Koenig, 1987, Benson, 1977, Contractor FJ and Lorange P., 1988), resist and survive on the market by realizing competitive advantages but conceiving their independence (Jolly D., 2002). Thus, they adopt a new organizational structure or an inter-organizational relationship that focuses on the sharing of skills, the exchange of resources and association of all or part of the activities, unification of objectives, and assuming their responsibilities by sharing profits, losses and risks.

Strategic alliances are Strategor (1997): " An association between competing or potentially competing firms that choose to carry out a specific project or activity by coordinating the skills, resources and resources required rather than being competition with each other on the activity concerned, to merge with each other or to dispose of or acquire business. ".

\subsection{Alliance Typology}

Mowla, 2012; Tonnel, 2012; Narheke and Samuelson, 2014 also showed that there are different typologies of strategic alliances depending on the objectives of the allies.

The standard analysis of alliances states that there are only two types: business alliances that are vertical partnerships and strategic alliances (Jamila M., 1992) that include additive alliances, joint integration alliances, and alliances. (Dussauge P. and Garette B., 1991) It is rather a horizontal partnership (Belgacem B, 2003) based on the configuration of the alliance and the organization of tasks between the different partners.

There are 3 big types of alliances:

Complementary alliances: they are concerned with two actors who unite by coupling competences and advantages that differ from one to another. So each ally must take responsibility for the tasks related to his own skills.

Joint integration alliances: they aim to achieve economies of scale. For example, banks that have establised this form of alliance can reduce research and development costs and limit the amount of each partner's investment.

Pseudo-concentration alliances: They consist of a forum of some banks that develop, produce and sell a common product; therefore this type of alliance has a high degree of commitment from each partner. The advantages of this alliance are that allies have the same skills and create, produce and market the same product.

\subsection{Banking Strategic Alliances}

The specificities of the banking activity explain the delicacy and the sensitivity of the organization and the management of these establishments. In fact, each bank must first study 
and determine its position on the sector in relation to its competitors and then determine its own strategy.

The alliances between the banks are one of the strategies of rapprochement that marked the global economic and financial sphere from the 80s. Certainly, this era is often considered as a transition phase escorted by a storm of mutations and deregulations. This, therefore, explains the reliance of some banks to ally in order to face the threats of an environment that is often in perpetual evolution, reach competitive positions and ensure their survival by improving their performance (Christopher Akpotu, Tamunosiki-Amadi Jasmine, 2016). Indeed, this strategy (Contractor and Lorange, 1988, Dussauge P., 1990, Koenig, 1990) is considered as an opportunity or a means of generating performance and creating a competitive advantage. It is in addition a theme that has been among the concerns of theoretical and academic researchers. Various results have been established that have given rise to different conclusions and findings. Also, like every strategy applied by companies, banking alliances can be financially beneficial through maximizing profits, minimizing risks, maintaining a good reputation through its brand image, improving skills and increased market share (Amin and Hossain 2013). Thus, the success or failure of an alliance between two companies depends on several factors such as: the convergence of objectives, the degree of understanding, the confidence and the weight of the allies,

A banking alliance is a strategy applied to meet the demands of a new context dominated by intense competition. Banks differ in their specificities and the particularity of their activities, this characteristic can be a determinant of the banking strategic alliance. The banking sector is therefore a favorable ground for the creation of alliances.

In addition, the strategic alliance plays a key role in improving the performance of banks, while ensuring their ability to compete and eradicate competitive positions (Barney, 1991, Combs and Ketchen, 1999 (Newbert , 2007) .Thus, it has often been considered as a solution likely to reassure the survival of a company (Lambe et al., 2002) and besides, strengthen its relations with its stakeholders and become more adept at managing its environment. internal and external and in return strengthen financial stability (Cummings and Holmberg, 2012, Schilke and Goerzen, 2010, Ireland et al., 2002, Rothaermel and Deeds, 2006), Draulans et al., 2003, Heimeriks et al., 2009 Schilke and Goerzen, 2010). Without an alliance, banks will not have the opportunity or the power to realize all these benefits (Bouayad and Legris (1996).

\subsection{Strategic Alliances: Public Banks \& Foreign Banks}

The gradual expansion of the indicators of size, profitability, value creation and market share, require banks to open up to the outside and collaborate with other banks in order to resist to the different mutations and ensure their survival in the longest possible time.

The alliance between banks is a strategy that can be defined by the cooperation of public banks with foreign banks. It aims to expand its market share in order to maximize its annuities and consequently to have a good image on the territory, strengthen its funds, acquire new skills and new advanced ideas.

This strategic form is often used by banks which want to move towards the acquisition of 
competitive positions in their sector and face in return intense competition so that they can ensure its sustainability and ensure its survival. In addition, it multiplies opportunities (Kotler et al., 2008) for allies to penetrate international markets.

The alliance between a foreign bank and a national bank makes it possible to improve the quality of the financial services offered, diversify the products offered, carry out joint projects and increase competition in the market. This strategy is carried out either with banks that are suffering from certain difficulties or with successful banks to improve their levels of competitiveness.

\subsection{Strategic Alliance: Public Banks and Private Banks}

The current context is characterized by economic, technological and social financial changes as well as increased competition in all sectors, particularly the banking sector. This , proves the need to sometimes resort to the strategy of alliance between public bank and bank.

The alliance between public banks and private banks is a formal agreement that is carried out partially or totally, whose objective is the unification of means and to collaborate in order to face the competition, resist, strengthen their capacities, overcome the difficulties of finance, manage risks, expand their market share and guarantee their survival, improve the image of the bank, expose a new range of products to be sold to a clientele either in the national market or in the international market. Rather, it is a collaboration that requires allies to have the same goals and directions that are aimed at exploring a foreign market, or time-based visions that consider a long-term alliance.

Alliance between national bank and foreign bank means an agreement settledd in order to achieve international expansion and conquer important parts in the foreign market through the establishment of networks of banks, agencies and representative offices, the improvement of financial resources, the granting of syndicated loans to finance major projects, diversification of products, improvement of the quality of services, the financing of business investments and the majority of sectors of an economy.

\subsection{Key Success Factors of Strategic Alliances}

The success of a strategic alliance depends on several factors, including the interest of allies in problem solving, their reliability and their involvement in value creation and the consolidation of resources and capabilities (Uddin dan Akhter, 2011). The consideration of operational and relational risks in the choice of partners and the identification of the appropriate alliance structure must be done to minimize potential risks and ensure the achievement of competitive advantage (Uddin and Akhter, 2011).

\section{Strategic alliance agreements are affected by many factors.}

Complementarity between allies: when the company decides to join forces, it must first make choices and comparisons to determine its partners. It is often desirable to align with former allies to increase the alliance's chances of success (Sorrentino and Garraffo 2012, Shi et al., 2012, Gulati et al., 2009, Kim, 2011, Xiong and Bharadwaj, 2011). In this case, it is an alliance with repetitive partners (Pangarkar \& Wu, 2013, Christoffersen, 2013). 
Social capital: Social capital is an essential driver for the conclusion of the alliance contract (Xiong and Bharadwaj, 2011, Sorrentino \& Garraffo, 2012).

Information: It is an essential factor for the success of an alliance. However, in most agreements the uncertainty and ambiguity of the information are never absent. As a result, the ability to reduce information asymmetries and the search for perfect information ensures cost reduction.

The commitment of the different allies: It is also a key factor in ensuring the success of the alliances (Rampersad, Quester and Troshani, 2010, Chen, Lee and $\mathrm{Wu}, 2008$ ), reducing opportunistic behavior and building confidence among the allies ( Ramprasad et al., 2010);

Coordination: The agreement between the two parties defines the boundaries and tasks of each ally according to objectives that should be consistent Rampersad et al. (2010)

Interdependence: As the strategic alliance requires profit sharing, it also gives rise to responsibility for assuming the risks (Rodriguez, 2002).

Trust: It is a key success factor for alliances that manages conflicts (Anderson and Narus, 1990) and the success of this collaboration (Green, 2003), Glaister and Buckley, 1999, Greve et al., 2010). Trust often results from repetitive alliances between the same partners (Gulati, 1995). Musarra (2016) shows that the ambiguity and obscurity that characterize a strategic alliance can influence decisions and consequently negatively impact performance.

Control: Control is a key factor in monitoring and monitoring different stages of the alliance process throughout the exercise as well as monitoring the behaviors of different parties (Gittell, 2000).

Duration: A strategic alliance can be long term as it can be in the short term (Rothaermel 2012). Certainly at the conclusion of the contract the decision of the duration of the alliance is dependent on the objectives of each ally (Wong, 2004).

The length of membership: It is another factor determining the company's strategic alliances, which allows companies to enter complex new markets (Kumari, 2001).

The Agreement: In a strategic alliance, the agreement could take the form of a contract or a formal declaration of collaboration. The agreement is designed to establish the basic rules, responsibilities, processes and expectations of each party. For strategic alliances to be accepted across the organization, the agreement should be signed by the CEO and terminated at that level.

Strategic objectives: The end result of a strategic alliance should give both parties a substantial market, technology or cost advantage

Innovation and skills: The enhancement through an alliance strategy are crucial determinants for this cooperation. This is explained by the fact that banks around the world are institutions that rely on technology in the majority of their operations, so it is reasonable to consider this determinant as support for improving banking performance. (Kelly et al., 2002). 


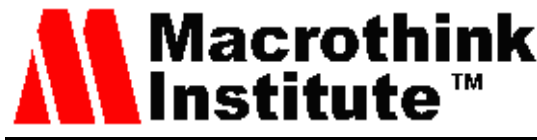

The alliance ensures financial stability and improves the profitability of commercial banks (Kabubo, 1998, (Uddin dan Akhter, 2011) .The formation of banking alliances is regulated during the trading period. banks maintain financial benefits and asset growth, the funds are primarily provided by the state Each commercial bank is required to disclose all information about its financial statements and alliance strategies at the end of each year This transparency makes it possible to judge the bank's performance and rectify the shortcomings relating to the bank's management and governance methods, and the managers have an opportunity to draw up critical reports on the bank's situation and the strategy applied. The regulator on its part intervenes to propose solutions likely to improve the degree of profitability of the banks through the proposal to apply strategic supervisory alliances.

Indeed, banking alliances bring banks closer together and, on top of that, increase the chances of connecting with foreign banks, which favors the opportunities to link them with global markets on an international scale.

The ridge of alliance with other party, consists to banks can face the difficulties that may intervene. Admittedly, thanks to this strategy they will be able to provide the necessary resources, develop or improve products or services, increase the range of products or services intended to be exposed to the market with a better quality, which consequently improves its quality and its added value.

\subsection{Strategies of Alliance and Cost Efficiency of Saudian Commercial Banks: Empirical Validation}

The Vision 2030 places a premium on public-private partnership. The latter is seen as an alternative to both finance and manage complex public infrastructure, in a context where the state is forced to imagine new solutions and new approaches to mobilize all economic actors (Yaya, 2005).

Under the pressure of a crisis, or in view of the opportunities that arise in a market, Saudi banks seek new growth opportunities, mostly in the context of existing activities, but also by improving their efficiency through development of an alliance strategy (a public-private alliance or a public-foreign alliance) as a new management mode.

The question of the positive effects of the presence of foreign banks has been summarized in several World Bank studies. They focus on the following two elements: (Ross Levine, 2003).

"Increasing the efficiency of the domestic banking sector: Profitability is improving due to increased competition. The entry of these banks favors the introduction of new management technologies and innovations in the design of services"

"Constitution of a better legal framework and better supervision of the domestic banking sector: The entry of foreign banks improves transparency and reduces the vulnerability of the banking sector to domestic crisis ".

In short, the recourse of Saudi public banks to the private sector, as part of a new form of public-private co-operation with the aim of improving their efficiency, is a necessity in a context of globalization to meet a demanding performance. 


\section{Macrothink}

Business and Economic Research

ISSN 2162-4860

2019, Vol. 9, No. 1

The present article is part of this research perspective, the aim being to determine the effects of the alliance strategy on the efficiency of the Saudi banking sector. The characterization of such effects is based on an empirical investigation and will refer to an inducto-deductive approach to differentiate the implications of the said alliances.

This objective has recommended us to present in the first part the methodological device allowing this characterization and to carry out the empirical validation and the evaluation of the effects as well as the discussion of the main results in the second part.

\section{Methodology}

This part will be devoted to the presentation of theoretical and empirical methodologies adopted in order to answer the following question: what is the impact of the alliance strategy on the cost efficiency of Saudi firms?

It is therefore necessary to question the role of the Public and Foreign banks and Public and Private banks alliance strategies in improving the cost efficiency of Saudi commercial banks.

The purpose of this part is to provide an empirical perspective to this question. To do this we formulate the following two propositions that we test on the basis of a sample of nine Saudi commercial banks.

Referring to the theory of market efficiency associated with the signal theory, we formulate the two propositions quoted below and will put the conceptual model to the test by establishing the links between the alliance strategies and the efficiency cost of Saudi banks.

\subsection{Hypothesis}

Proposition 1: What is the impact of the public-foreign alliance strategy on the efficiency of Saudi commercial banks?

Proposal 2: What is the impact of the public-private alliance strategy on the efficiency of Saudi commercial banks?

\subsection{Sample and Data Collection}

Our sample is composed of 09 Saudi commercial banks, these banks will be divided into 3 Saudi banking poles;

A public banking center: It groups together $\mathrm{X}$ and $\mathrm{Y}$ while preserving the specificity of each of these three banks.

A private banking center: $\mathrm{A}, \mathrm{B}$ and $\mathrm{C}$.

A foreign banking pole: $\mathrm{E}, \mathrm{F}$, and $\mathrm{G}$.

\subsection{Econometric Specification}

Our econometric model highlights the correlation between alliance strategies and the cost efficiency of Saudi banks. The modelis particularly interested in examining the ability of alliance strategies to become an explanatory factor for the cost efficiency of Saudi 
commercial banks. We begin by regressing ordinary least squares efficiency on a series of explanatory variables.

In order to determine the impact of alliance strategies on the efficiency of Saudi commercial banks, we developed a model that reflects the purpose of our research, namely, to analyze the impact of the alliance strategy on efficiency cost of the banks in our sample.

Efficiency bank cost $=$ constant + variable alliance strategy + control variables + error term .

The conceptual research model can be tested using two different regression equations that will be estimated simultaneously. The first regression, aims to test the impact of the public-foreign alliance on the efficiency of the banks in our sample. As for the second regression, it is carried out to test the impact of the public-private alliance on the latter.

$$
\begin{aligned}
& E F F_{T}=\beta_{0}+\beta_{1} \text { alliance }_{p u b, E t r}+\beta_{2}+B_{3}+\beta_{4} T E_{p u b, E t r}+\beta_{5} T D A_{p u b, E t r}+\beta_{6} R O A_{p u b, E t r} \\
& +\beta_{7} \operatorname{Prod}_{\text {pub }, \text { tr }}+\varepsilon_{t} \\
& E F F_{T}=\gamma_{0}+\gamma_{1} \text { alliance }_{\text {pub,Priv }}+\gamma_{2} T C A_{\text {pub,Priv }}+\gamma_{3} \text { Trans }_{\text {pub,Priv }}+\gamma_{4} T E_{\text {pub,Priv }} \\
& +\gamma_{5} \text { TDA } A_{\text {pub,Priv }}+\gamma_{6} \text { ROA }_{\text {pub,Priv }}+\gamma_{7} \operatorname{Prod}_{\text {pub,Priv }}+\varepsilon_{t}
\end{aligned}
$$

We will use econometric estimation techniques. To do this we will consider the observations that have been identified as being a time series.

\section{Presentation and interpretation of the results of the hypothesis verification tests.}

This part will be devoted to empirically test the two prepositions presented. First we will present the results and analyzes of the descriptive statistics, then we analyze the results of the tests that are carried out for the verification of the conditions of use of the regression, and finally the discussion and the interpretation of the results.

\subsection{Presentation of Results on Descriptive Statistics}

Before checking for correlations between the independent variables, we will first attempt to present the descriptive statistics of the variables used.

Table 1: provides a description of the 8 independent variables through the following elements: mean, median, standard deviation and extreme values (minimum and maximum).

Table 1. Descriptive statistical presentation of the variables used

\begin{tabular}{r|rrrrr} 
Variable & Obs & Mean & Std. Dev. & Min & Max \\
\hline TAPUBETR & 16 & 5.39802 & .1493855 & 5.143824 & 5.567533 \\
TAPUBPRIV & 16 & 5.401057 & .1266509 & 5.166297 & 5.531165 \\
TEpubetr & 16 & .6330498 & .1775445 & .3068531 & .7624434 \\
TEpubpriv & 16 & .6271447 & .1860172 & .2915382 & .7517888 \\
ROApubetr & 16 & .0000483 & .0000818 & -.0001782 & .0001193 \\
\hline ROApubpriv & 16 & .0000523 & .0000486 & -.000055 & .0001124 \\
prodpubetr & 16 & 8.595987 & .320395 & 8.03765 & 8.958886 \\
prodpubpriv & 16 & 8.639953 & .3983577 & 7.979816 & 9.158182 \\
tdapubpriv & 16 & .4806056 & .1438191 & .1964788 & .6221218 \\
tdapubetr & 16 & .4624205 & .136632 & .2135502 & .5984912
\end{tabular}




\section{I Macrothink}

Business and Economic Research ISSN 2162-4860 2019, Vol. 9, No. 1

According to the table above, the examination of the different statistical tests reveals that the hypotheses for the estimation of this multiple regression are verified. This leads us to the study of multicollinearity between variables in order to verify our first hypothesis. For this, in a first step an analysis of the matrix of correlations between the explanatory variables will be performed.

\section{H1: multicollinearity does not affect the forecast of the variable to be explained.}

An analysis based on the examination of the pearson correlation matrix reveals, indeed, a multiple problem of multicollinearity (see the relations presenting coefficients of correlation higher than 0.8 in table 2.

Table 2. Correlation Between the Variables of the First Regression

\begin{tabular}{|l|l|l|l|l|l|}
\hline & alliance pub,etr & TE pub,etr & ROA pub,etr & Prod pub,etr & TDA pub,etr \\
\hline alliance pub,etr & 1.0000 & & & & \\
\hline TE pub,etr & 0.0438 & 1.000 & & & \\
\hline ROA pub,etr & 0.5250 & -0.3475 & 1.000 & & \\
\hline Prod pub,etr & -0.2641 & $\mathbf{0 . 9 2 8 7}$ & -0.4446 & 1.000 & \\
\hline TDA pub,etr & -0.1087 & $\mathbf{0 . 9 4 9 8}$ & -0.3371 & $\mathbf{0 . 9 3 5 2}$ & 1.000 \\
\hline
\end{tabular}

The correlation matrix shows that some correlations are stronger than others, we can already suggest some associations: (TE pub, etr / Prodpub, etr),

(TE pub, etr / TDA pub, etr) and (Prodpub, etr / TDA pub, etr).

Table 3. Correlation Between the Variables of the First Regression

\begin{tabular}{|l|l|l|l|l|l|}
\hline & Alliancepub,priv & TE pub,priv & ROA pub, priv & Prod pub, priv & TDA pub,priv \\
\hline alliance pub,priv & 1.0000 & & & & \\
\hline TE pub,priv & -0.5971 & 1.000 & & & \\
\hline ROA pub,priv & 0.7037 & -0.3897 & 1.000 & & \\
\hline Prod pub,priv & -0.5875 & $\mathbf{0 . 8 7 9 0}$ & -0.5109 & 1.000 & \\
\hline TDA pub,priv & -0.5171 & $\mathbf{0 . 9 2 6 1}$ & -0.4382 & $\mathbf{0 . 9 4 9 2}$ & 1.000 \\
\hline
\end{tabular}

Source: by the author

With regard to the correlation between the variables of the first regression, the correlation matrix shows a strong correlation between the variables: (TE pub, priv / Prodpub, priv), (TE pub, priv / TDA pub, priv) and ( Prodpub , priv / TDA pub, priv).

A significant correlation between the two variables TE pub, priv and Pradpub, priv and with a high coefficient of correlation (0.8790);

A significant correlation of (0.9261) between pub, priv and pub ad, priv;

A strong correlation of (0.9492) between the two variables $\llbracket \operatorname{prod} \rrbracket_{-}$(pub, priv) and (ADD $\square$ _ (pub, priv).

In summary, it can already be seen that the correlation matrices above show a strong 
correlation between the variables within each regression. It is necessary to deal with a problem of multicollinearity.

Before the application of the Principal Component Analysis (PCA) technique, the 2 estimated regressions were:

$$
\begin{gathered}
\mathrm{EFF}_{\mathrm{T}}=\boldsymbol{\beta}_{0}+\beta_{1} \text { alliance }_{\text {pub,Etr }}+\beta_{2} \mathrm{TE}_{\text {pub,Etr }}+\beta_{3} \mathrm{TDA}_{\text {pub,Etr }}+\beta_{4} \mathrm{ROA}_{\text {pub,Etr }}+\beta_{4} \operatorname{Prod}_{\text {pub,Etr }}+\varepsilon_{\mathrm{t}} \\
\mathrm{EFF}_{\mathrm{T}}=\gamma_{0}+\gamma_{1} \text { alliance }_{\text {pub,Priv }}+\gamma_{2} \mathrm{TE}_{\text {pub,Priv }}+\gamma_{3} \mathrm{TDA}_{\text {pub,Priv }}+\gamma_{4} \mathrm{ROA}_{\text {pub,Priv }}+\gamma_{5} \operatorname{Prod}_{\text {pub,Priv }}+\varepsilon_{\mathrm{t}}
\end{gathered}
$$

Après l'application de la technique de l'Analyse en Composantes Principales (ACP), les deux régressions s'écrivent:

$$
\begin{aligned}
& \mathrm{EFF}_{\mathrm{T}}=\boldsymbol{\beta}_{0}+\beta_{1} \text { alliance }_{\text {pub,Etr }}+\beta_{2} \operatorname{Comp}_{1}+\varepsilon_{\mathrm{t}} \\
& \mathrm{EFF}_{\mathrm{T}}=\gamma_{0}+\gamma_{1} \text { alliance }_{\text {pub,Priv }}+\gamma_{2} \operatorname{Comp}_{2}+\varepsilon_{\mathrm{t}}
\end{aligned}
$$

- Examination of normality of variables: verification of $H_{-}(1.1)$

the search for behavioral causes to the presence of skewness and kurtosis in the distribution of the variables of the study requires the use of the "sktest" command of the STATA software, we can test the hypothesis H_O of normality of the variables. In fact, the normality test of the variables presented in the table below shows that all the variables are normal for all the two equations (see table 3 ).

Table 3. SKewness / Kurtosis tests for normality

\begin{tabular}{|l|l|l|l|l|}
\hline Variables & Pr(SKewness) & $\operatorname{Pr}$ (Kurtosis) & Ad chi 2 & Prob > chi 2 \\
\hline EFF & & & & \\
\hline alliance Pub,Etr & 0.6841 & 0.2273 & 1.84 & 0.3986 \\
\hline alliancePub,Priv & 0.7518 & 0.3302 & 1.16 & 0.5606 \\
\hline TE Pub,Etr & 0.0269 & 0.9504 & 4.9 & 0.0864 \\
\hline TE Pub,priv & 0.0286 & 0.8446 & 4.84 & 0.0887 \\
\hline ROA Pub,Etr & 0.6606 & 0.6333 & 0.43 & 0.8055 \\
\hline ROA Pub,priv & 0.1399 & 0.7399 & 2.64 & 0.2673 \\
\hline Prod Pub,Etr & 0.9533 & 0.1866 & 1.99 & 0.3701 \\
\hline Prod Pub,priv & 0.0440 & 0.8618 & 4.31 & 0.1161 \\
\hline TDA Pub,Etr & 0.0592 & 0.6906 & 4.03 & 0.1332 \\
\hline TDA Pub,Priv & 0.0804 & 0.7398 & 3.61 & 0.1644 \\
\hline
\end{tabular}

Source:

The Kaiser-Meyer-Olkin index is used to test hypothesis $H_{-}$(1.2). According to our calculations (Table 3), Kaiser's accuracy measure is 0.77 for the first regression and 0.75 for the second and can be qualified as "good". We can therefore, assume us that the correlations between our variables are good quality.

Before establishing the principal component analysis, Bartlett's sphericity test should be conducted to test the hypothesis 


\section{Macrothink}

H_2. For the Bartlett sphericity test, here are the results obtained under STATA.

Table 4. Bartlett's sphericity test and the overall KMO index before a PCA

\begin{tabular}{|c|l|l|}
\hline & Regession 3.1 etr & Regréssion 3.2 \\
\hline Kaiser-Meyer-Olkin Measure of Sampling Adequacy & 0.774 & 0.752 \\
\hline Bartlett's Test of SphericityApprox C hi-Square & & \\
Df & 61.986 & 59.002 \\
Sig & 6 & 6 \\
$\mathbf{H}_{\mathbf{0}}$ : variables are not intercorrelated & 0.000 & 0.000 \\
\hline
\end{tabular}

Source: Based on our calculations

(Table 4), the calculated Bartlett sphericity test value is statistically significant at the 5\% risk threshold for both regressions. We can therefore reject the null hypothesis that our data comes from a population for which the matrix would be an identity matrix. Therefore not all the correlations are equal to zero. The conditions for conducting an ACP are therefore met. It is therefore possible to initiate an ACP on these data.

All factorization conditions are met, so we can conduct our factor analysis

After extracting the diagonal, we have the following KMOs:

Table 5. Kaiser-Meyer-Olkin measure of sampling adequacy

\begin{tabular}{|l|l|}
\hline VARIABLES & K-M-O \\
\hline Variables régréssion 3.1 & 0.7929 \\
\hline TE Pub,Etr & 0.7106 \\
\hline ROA Pub,Etr & 0.7931 \\
\hline Prod Pub,Etr & 0.7539 \\
\hline TDA Pub,Etr & $\mathbf{0 . 7 7 4 3}$ \\
\hline Overall & \\
\hline Variables régréssion 3.2 \\
\hline TE Pub,priv & 0.8301 \\
\hline ROA Pub,priv & 0.8263 \\
\hline Prod Pub,priv & 0.7454 \\
\hline TDA Pub,Priv & 0.6792 \\
\hline Overall & $\mathbf{0 . 7 5 1 5}$ \\
\hline
\end{tabular}

Source: our own calculations under STATA

From the table above, it can be noted that, according to Kaiser's scale, there are five variables that have a KMO in the "Good" range, two variables are in the "Very Good" range. well "and one remaining is in the" Middle "range. This reassures us that each of the variables considered has a certain degree of correlation with the others. So we can proceed to the ACP with all these variables

the first component "comp1" is connected to four variables ( \TE ${ }_{-}(\mathrm{Pub}, \mathrm{Etr})$, ROA ${ }_{-}$ 


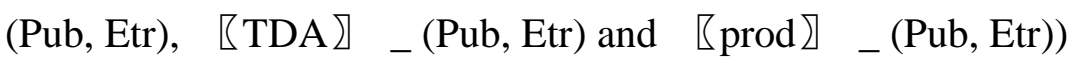

- the second component "Comp2" takes into account the following four variables: ( \TE】 _

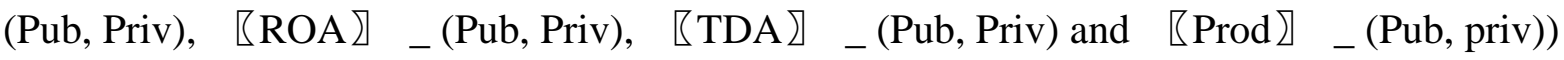

\section{- Presentation and interpretation of the results of the regression model}

This part is devoted to presenting the results of the estimation of the parameters of the model by the MCO.

Table 6. Presentation of the estimation of model parameters by OLS

\begin{tabular}{|c|c|c|c|c|}
\hline Variables explicatives & $t$ de Student & $p>|t|$ & $t$ de Student & $p>|t|$ \\
\hline \multicolumn{5}{|c|}{ Régression 3.1: $\boldsymbol{E F F}_{T}=\boldsymbol{\alpha}_{\mathbf{0}}+$ alliance $_{\text {Pub,etr }}+$ Comp $_{1}+\varepsilon_{T}$} \\
\hline alliance $_{P u b, e t r}$ & 3.32 & $0^{0.006 * *}$ & - & - \\
\hline $\operatorname{Comp}_{1}$ & -2.71 & $0.018^{* *}$ & - & - \\
\hline Constante & 0.89 & 0.89 & - & - \\
\hline$R^{2}$ & \multicolumn{2}{|l|}{0.458} & - & - \\
\hline Prob $>F$ & \multicolumn{2}{|l|}{0.0185} & - & - \\
\hline \multicolumn{5}{|c|}{ 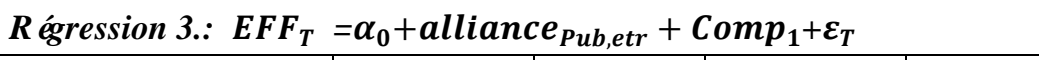 } \\
\hline alliance $_{\text {Pub,priv }}$ & - & - & 2.80 & $0.018^{* *}$ \\
\hline $\mathrm{Comp}_{2}$ & - & - & -2.19 & $0.053^{*}$ \\
\hline Constante & - & - & 0.67 & 0.514 \\
\hline$R^{2}$ & \multicolumn{2}{|l|}{-} & \multicolumn{2}{|l|}{0.36} \\
\hline Prob $>F$ & \multicolumn{2}{|l|}{-} & \multicolumn{2}{|l|}{0.052} \\
\hline
\end{tabular}

*The coefficient is significant at the threshold of 0.10

** The coefficient is significant at the 0.05 threshold

*** The coefficient is significant at the 0.01 level

Before interpreting the results of the model. We will first verify whether the assumptions underlying a multiple linear regression are true. We will verify the assumptions of normality of residuals, homoscedasticity of hazards and autocorrelation.

Residue Normality Test: Check H_2

The overall relevance of the regression is based on the assumption of normal distribution $\mathrm{N}$ $(0 . \sigma)$ of the error term of the regression equation.

Table 7. SKewness / Kurtosis tests for normality

\begin{tabular}{|l|l|l|l|l|l|}
\hline \multicolumn{5}{|l|}{ Regression 3.1 } \\
\hline variable & Obs & $\operatorname{Pr}$ (SKewness) & $\operatorname{Pr}$ (Kurtosis) & Ad chi 2 & Prob > chi 2 \\
\hline Residu1 & 16 & 0.7887 & 0.6219 & 0.31 & 0.8543 \\
\hline \multicolumn{5}{|l|}{ Regression 3.2 } \\
\hline variable & Obs & $\operatorname{Pr}$ (SKewness) & Pr (Kurtosis) & Ad chi 2 & Prob> chi 2 \\
\hline Residu2 & 16 & 0.2124 & 0.4360 & 2.49 & 0.2887 \\
\hline
\end{tabular}

Source: our own calculations 


\section{Macrothink}

Business and Economic Research

ISSN 2162-4860 2019, Vol. 9, No. 1

Based on the results (from Table 3.16), the probabilities of rejecting the normality assumption of residues are $85.43 \%$ AND $44.16 \%$ respectively for equations (3.1) and (3.2). This does not reject the hypothesis of normality. residues for both equations of the model.

In our study, we take the Breusch-Pagan test to test for heteroscedasticity and therefore check hypothesis H_3.

Table 8. Heteroskedasticity Test Results (Breusch-Pagan)

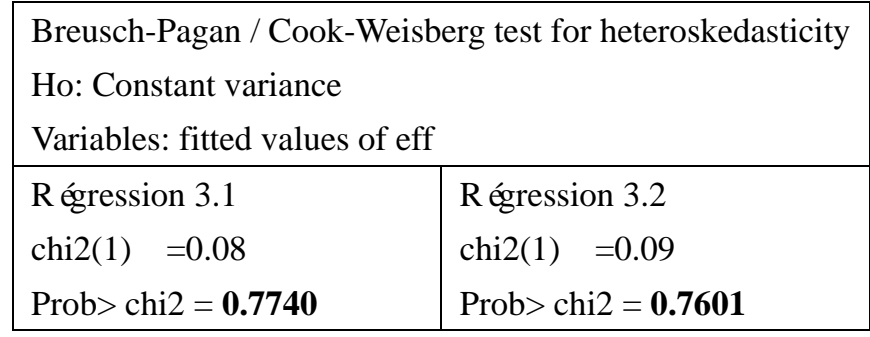

Source: our own calculations

The results of the heteroscedasticity test show that all the probabilities associated with the coefficients are all greater than 0.05 . therefore, we reject the hypothesis $\mathrm{H}_{-} 1$ of heteroscedasticity and assume the homoscedasticity of the residues.

Data independence is a necessary condition for a regression study. Indeed, the autocorrelation of errors test makes it possible to check H_4. In our model, we use the Durbin-Watson statistical test to check the self-correlation of errors.

This statistic is of the order of 2,008 and 1,773 respectively for the two equations (3.1) and (3.1).

Reading the DW table gives us the following results:

Extrait de la table de DW

$p=$ nombre de variables explicatives, $n=$ nombre d'observations

\begin{tabular}{|c|c|c|c|c|c}
\hline \multirow{2}{*}{$\mathrm{n}$} & \multicolumn{2}{|c|}{$\mathrm{p}=1$} & \multicolumn{2}{c|}{$\mathrm{p}=2$} & \\
\cline { 2 - 6 } & $\mathrm{d} 1$ & $\mathrm{~d} 2$ & $\mathrm{~d} 1$ & $\mathrm{~d} 2$ & \\
\hline 15 & 1,08 & 1,36 & 0,95 & 1,54 & \\
16 & 1,10 & 1,37 & 0,98 & 1,54 & \\
17 & 1,13 & 1,38 & 1,02 & 1,54 &
\end{tabular}

Table 9. Autocorrelation error test (Durbin-Watson)

\begin{tabular}{|l|l|l|l|}
\hline \multicolumn{3}{|l|}{ Test de Durbunwatson pour $\mathbf{n = 1 6}$ et $\mathbf{p = 2}$} \\
\hline \multicolumn{2}{|l|}{ régréssion3.1 } & \multicolumn{2}{l|}{ Régréssion3.2 } \\
\hline $\mathrm{d}$ & 2.008 & $\mathrm{~d}$ & 1.773 \\
\hline $\mathrm{dL}(\mathrm{d} 1)$ & 0.98 \\
\hline $\mathrm{du}(\mathrm{d} 2)$ & 1.54 \\
\hline $4-\mathrm{dL}$ & 3.02 \\
\hline $4-\mathrm{du}$ & 2.46 \\
\hline
\end{tabular}


After these results, we find that we are in the region:

of <d <4-du: The hypothesis of no autocorrelation of errors from where:

Examination of the different statistical tests reveals that the assumptions for the estimation of this multiple regression are fully verified.

\section{Discussions of regression results}

After carrying out the verifications of the basic assumptions mentioned above, we will proceed to the interpretation of the final results of the two regressions.

Summing up, we can see that the entering into of an alliance agreement allows Saudi commercial banks to improve their level of efficiency. This means that strategic alliances are an opportunity and an interesting strategic option for the latter.

Public-private and public-foreign alliances are able to improve the efficiency of public banks, increase their competitiveness and reduce their fragility

\section{Conclusion}

Assessing the impact of alliance strategies on firm efficiency has been an important part of management research in the recent decades.

In this research study, we determined in a relationship the impact of an alliance strategy on the efficiency of Saudi commercial banks.

From this part, we can say that the strategies of alliances have attracted the attention of several authors, each of them apprehended it by referring to his own discipline.

Thus, the study of the relationship between the strategies of alliances and efficiency of the Saudi Commercial Banks aims at the same time the elaboration of a theoretical and empirical study.

- On the theoretical level, we have given an overview of the concepts and theories that justify the existence of a relationship between cooperation strategies and efficiency.

-on the empirical level, we have uncovered the different results of our model. The conceptual research model is tested using two different multiple linear regression equations and were estimated by the ordinary least squares (OLS) method on temporal data. At first, we performed a descriptive analysis of the variables used in this study, and then we conducted an econometric study to determine the relationship between alliance strategies and efficiency.

This econometric study, however, required the mobilization of several econometric tests (residue normality test, heteroscedasticity test and autocorrelation error test) to respect the methodology in this area and to obtain valid and reliable results.

In summary, the results we came up with affirm that:

Foreign cooperation agreements allow Saudi public banks to improve their efficiency. Because this type of cooperation allows these firms to save their costs, share their risks, 
benefit from a complementary technological combination, learn from their foreign partner new management methods, information systems, research and development programs and especially the experience of this foreign partner.

Thanks to the alliance, Saudi public banks will make economies of scale to significant market share and will also reduce their costs.

The partnership with the private sector allows Saudi public banks to benefit from several advantages and achieve goals in terms of efficiency and effectiveness, which they could not do it alone.

In conclusion, it has been noted that the creation of an alliance agreement can be considered as the preferred route by the Saudi public banks to ensure their efficiency, increase their competitiveness and minimize their fragility.

\section{References}

Agarwal, R., \& Bayus, B. L. (2002). The market evolution and sales takeoff of product innovations. Management Science, 48, 1024-41. https://doi.org/10.1287/mnsc.48.8.1024.167

Amici, A., Fiordelisi, F., Masala, F., Ricci, O., \& Sist, F. (2013). Value creation in banking through strategic alliances and joint ventures. Journal of Banking \& Finance, 38, 1386-1396. https://doi.org/10.1016/j.jbankfin.2012.03.028

Amici, A., Fiordelisi, F., Masala, F., Ricci, O., \& Sist, F. (2011). Value Creation in Banking Through Strategic Alliances and Joint Ventures. http://dx.doi.org/10.2139/ssrn.1895325

Anderson, J. C., \& James, A. N. (1990). A Model of Distributor Firm and Manufacturer Firm Working Partnerships. Journal of Marketing, 54(1), 42-58.

https://doi.org/10.1177/002224299005400103

Barney, J. B. (1991). Firm resources and sustained competitive advantage. Journal of Management, 17, 99-120. https://doi.org/10.1177/014920639101700108

Belgacem, B. (2003). opportunité du partenariat pour la croissance des entreprises : cas des entreprises des industries manufacturières en Tunisie, Thèse, FSEG-Tunis.

Benson, J. K. (1977), Innovation and Crisis in Organizational Analysis. Sociological Quarterly, 18, 3-16. https://doi.org/10.1111/j.1533-8525.1977.tb02158.x

Bouayad, A., Legris, P. Y. (1996). Les alliances stratégiques, Dunod, Paris.

Chen, S. H., Lee, H. T., \& Wu, Y. F. (2008). Applying ANP approach to partner selection for strategic alliance. Management Decision, 46(3), 449-465.

https://doi.org/10.1108/00251740810863889

Chiou, I., \& White, L. J. (2005). Measuring the value of strategic alliances in the wake of a financial implosion: Evidence from Japan's financial services sector. Journal of Banking and Finance, 29, 2455-2473. https://doi.org/10.1016/j.jbankfin.2004.09.001

Christopher, A., \& Jasmine, T. A. (2016). Strategic Alliance and Operational Sustainability in 
the Nigerian Banking Sector. Review of Social Sciences, LAR Center Press, 1(8), 44-50.

Colombo, M. G., Grilli, L., \& Piva, E. (2006). In search of complementary assets: The determinants of alliance formation of high-tech start-ups. Research Policy, 35(8), 1166-1199. https://doi.org/10.1016/j.respol.2006.09.002

Contractor, F., \& Lorange, P. (1988a). Why Should Firm Co-operate? The Strategic and Economic Basis for Co-operative Ventures. In: Contractor, F. and Lorange, P. Cooperative Strategies in International Business, Lexington, MA: Lexington Books, pp. 3-28.

Contractor, F., \& Lorange, P. (1988b) Cooperative Strategies in International Business, Lexington, MA: Lexington Books. Cummings and Holmberg, 2012,

Davies, I., \& Arogundade, O. Y. (2014). Corporate Alliances: Rationale and Realization of Focused goals. Journal of Corporate Sustainability, 9(9), 102-177.

Dean, E., \& Yunus, K. (2001). An overview of strategic alliances. Management Decision, 39(3), 205-218, https://doi.org/10.1108/EUM0000000005452

Dussauge, P. (1990). Les alliances stratégiques entre firmes concurrentes. L'exemple des industries aérospatiale et de l'armement", Revue Française de Gestion, n080, p.5-16.

Eggers, J. P., \& Kaplan, S. (2009). Cognition and renewal: Comparing CEO and organizational effects on incumbent adaptation to technical change. Organ. Sci., 20(2), 461-477. https://doi.org/10.1287/orsc.1080.0401

Faems, D., Van Looy, B., \& Debackere, K. (2005). Interorganizational collaboration and innovation: Toward a portfolio approach. Journal of Product Innovation Management, 22(3), 238-250. https://doi.org/10.1111/j.0737-6782.2005.00120.x

Faulkner, D. (1995). International Strategic Alliances: Cooperating to Compete, McGraw-Hill Book Company.

Ferreira, M. P., Storopoli, J. E., \& Serra, F. R. (2014). Two decades of research on strategic alliances: analysis of citations, co-citations and themes researched. Revista de Administração Contemporânea, 18, 109-133. https://doi.org/10.1590/1982-7849rac20142022

Garvin, D. A., \& Lynne, C. L. (2006). Meeting the Challenge of Corporate Entrepreneurship. Harvard Business Review, 84(10).

Gittell, J. H. (2000). Organizing work to support relational co-ordination. International Journal of Human Resource Management, 11(3), 517-539.

https://doi.org/10.1080/095851900339747

Gleason, K. C., Mathur, I., \& Wiggins, R. A. (2003). Evidence on Value Creation in the Financial Services Industries through the Use of Joint Ventures and Strategic Alliances. Financial Review, 38(2). https://doi.org/10.1111/1540-6288.00043

Greve, C., \& Boardman, A. (2010). International Handbook on Public-Private Partnerships. Chelthenham: Edward Elgar, Chp. 16. 


\section{Al Macrothink}

Business and Economic Research ISSN 2162-4860 2019, Vol. 9, No. 1

Gulati, R. (1995b). Social Structure and Alliance Formation Patterns: A Longitudinal Analysis. Administrative Science Quarterly, 40, 619-652. https://doi.org/10.2307/2393756

Gulati, R., Lavie, D., \& Singh, H. (2009). The nature of partnering experience and the gains from alliances. Strategic Management Journal, 30(11), 1213-1233.

https://doi.org/10.1002/smj.786

Heimeriks, K. H., \& Duysters, G. (2009). Alliance capability as a mediator between experience and alliance performance: An empirical investigation into the alliance capability development process. Journal of Management Studies, 44, 25-49.

https://doi.org/10.1111/j.1467-6486.2006.00639.x

Heimeriks, K., Klijn, E., \& Reuer, J. (2009). Building capabilities for alliance portfolios. Long Range Planning, 42, 96-114. https://doi.org/10.1016/j.lrp.2008.10.005

Hoffmann, W. H. (2001). Management von allianzportfolios: Strategien für ein erfolgreiches unternehmensnetzwerk [Management of alliance portfolios: Strategies for a successful network of business partnerships]. Stuttgart, Germany: Schäffer-Poeschel.

Hoffmann, W. H. (2005). How to manage a portfolio of alliances. Long Range Planning, 38, 121-143. https://doi.org/10.1016/j.lrp.2005.03.001

Hoffmann, W. H. (2007). Strategies for managing a portfolio of alliances. Strategic Management Journal, 28, 827-856. https://doi.org/10.1002/smj.607

Ireland, R. D., Hitt, M. A., \& Vaidyanath, D. (2002). Alliance management as a source of competitive advantage. Journal of Management, 28, 413-446.

https://doi.org/10.1177/014920630202800308

Jamila, E. M. Hiérarchie et pouvoir dans les alliances. Cas d'application: les joint ventures, Revue du Financier, n¹07-1996.

Jamila, E. M. (1993). La joint venture: un outil stratégique, Direction et Gestion des Entrprises, $n^{\circ}$ 141-142, Mai-Août, p. 27-35.

Jamila, E. M. (1992). «La jointventure : analyse conceptuelle: réalitéset prospective, Thèse, Université de Nice Sophia- Antipolis, Institution d'Administration des Entreprises, Décembre.

Jolly, D. (2002). Un éclairage sur le concept d'alliance interentreprises, Humanisme \& Entreprises, 253, 69-81.

Jolly, D. (2002). Vers une typologie des alliances technologiques, Direction \& Gestion des Entreprises, 196-197, 121-130. https://doi.org/10.1051/larsg:2002030

Kale, P., \& Singh, H. (2009), Managing strategic alliances: What do we know now, and where do we go from here. Academy of Management Perspectives, 45, 45-62.

Kale, P., \& Singh, H. (2007). Building firm capabilities through learning: the role of the alliance learning process in alliance capability and firm-level alliance success. Strategic 
Management Journal, 28(10), 981-1000. https://doi.org/10.1002/smj.616

Kelly, M. J., Schaan, J. L., \& Joncas, H. (2002). Managing Alliance Relationships: Key Challenges in the Early Stages of Collaboration. $R \& D$ Management, 32(1), 11-22. https://doi.org/10.1111/1467-9310.00235

Kœnig, G. (1990). Management stratégique : vision, manoeuvres et tactiques. Paris: Nathan.

Kœnig, G. (1990). Management stratégique : vision, manoeuvres et tactiques. Paris: Nathan.

Kœnig, G. (1996). Management stratégique. Paradoxes, interactions et apprentissages. Paris: Nathan.

Koh, J., \& Venkatraman, N. (1991). Joint venture formations and stock market reactions: an assessment in the information technology sector. Academy of Management Journal, 34(4), 869-892.

Kristal, M., Huang, X., \& Roth, A. (2010). The Effect of an Ambidextrous Supply Chain Strategy on Combinative Competitive Capabilities and Business Performance. Journal of Operations Management, 28(5), 415-29. https://doi.org/10.1016/j.jom.2009.12.002

Kumari, V. (2001). Joint ventures bolster credibility of new players in India. National Underwriter, 105(14), 46.

Lambe, C. J., Spekman, R. E., \& Hunt, S. D. (2002). Alliance competence, resources, and alliance success: conceptualization, measurement, and initial test. Journal of the Academy of Marketing Science, 30(2), 141-158. https://doi.org/10.1177/03079459994399

Lorange, P., \& Roos, J. (1991). Why some strategic alliances succeed and others fail. Journal of Business Strategy, 12(1), 25-30. https://doi.org/10.1108/eb060095

Lorange, P., \& Roos, J. (1993). Strategic alliances: Formation, implementation, and evolution. New York:NY, Wiley.

Lunnan, R., \& Sven, H. (2008). Predicting and Measuring Alliance Performance: A Multidimensional Analysis. Strategic Management Journal, 29(5), 545-556.

https://doi.org/10.1002/smj.660

Madhok, A., Keyhani, M., \& Bossink, B. (2015). Understanding alliance: Adjustment costs and the economics of resource value. Strategic Organization, 13(2), 91-116.

https://doi.org/10.1177/1476127015580309

Marciukaityte, D., Roskelley, K., \& Wang, H. (2009). Strategic alliances by financial services firms. Journal of Business Research, 62, 1193-1199.

https://doi.org/10.1016/j.jbusres.2008.07.004

Mowla, M. M. (2012). An Overview of Strategic Alliance: Competitive Advantages in Alliance Constellations. Journal of Business Management and Corporate Affairs, 1(1), 1-10.

$\mathrm{Mu}$, J. F., \& Di Benedetto, C. A. (2011). Strategic orientations and new product commercialization: mediator, moderator, and interplay. $R \& D$ Management, 41(4), 337-359. 
https://doi.org/10.1111/j.1467-9310.2011.00650.x

Parmigiani, A., \& Rivera-Santos, M. (2011). Clearing a path through the forest: A meta-review of interorganizational relationships. Journal of Management, 37, 1108-1136. https://doi.org/10.1177/0149206311407507

Russo, M., \& Cesarani, M. (2017). Strategic Alliance Success Factors: A Literature Review on Alliance Lifecycle. International Journal of Business Administration, 8(3), 1-9. https://doi.org/10.5430/ijba.v8n3p1

Schilke, O., \& Goerzen, A. (2010). Alliance management capability: an investigation of the construct and its measurement. Journal of Management, 36(5), 1192-1219. https://doi.org/10.1177/0149206310362102

Uddin, M. B., \& Akhter, B. (2011). Strategic Alliance and Competitiveness: Theoretical Framework. International Refereed Research Journal, 2(1), 43-54.

Zineldin, M., \& Bredenlow, T. (2003). Strategic alliance: synergies and challenges: A case of strategic outsourcing relationship SOUR. International Journal of Physical Distribution \& Logistics Management, 33(5), 449-464. https://doi.org/10.1108/09600030310482004

\section{Copyright Disclaimer}

Copyright for this article is retained by the author(s), with first publication rights granted to the journal.

This is an open-access article distributed under the terms and conditions of the Creative Commons Attribution license (http://creativecommons.org/licenses/by/3.0/). 